\title{
Speciation of trace elements in human serum by micro anion exchange chromatography coupled with inductively coupled plasma mass spectrometry
}

\author{
Marco Malavolta*, Francesco Piacenza, Andrea Basso, Robertina Giacconi, Laura Costarelli, \\ Sara Pierpaoli, Eugenio Mocchegiani \\ National Institute of Health and Science on Aging (INRCA), Scientific and Technological Research Area, Nutrition and Ageing Centre, 60100 Ancona, Italy
}

\section{A R T I C L E I N F O}

\section{Article history:}

Received 26 April 2011

Received in revised form 3 October 2011

Accepted 5 November 2011

Available online 13 November 2011

\section{Keywords:}

HPLC-ICP-MS

Speciation

Trace elements

Human serum

\begin{abstract}
A B S T R A C T
Speciation analysis of essential trace elements in human serum provides important information on nutritional status and homeostatic mechanisms regulating transport processes, acute phase reactions, and protection against oxidative damage. Anion exchange high-performance liquid chromatography (HPLC) combined with inductively coupled plasma mass spectrometry (ICP-MS) has proved to be a useful tool in speciation. Here we describe a fast method that can be applied to carry out the speciation of $\mathrm{Fe}, \mathrm{Cu}$, $\mathrm{Zn}$, and Se in as little as $1 \mathrm{ml}$ of serum. The method employs monolithic anion exchange micro columns installed on a tandem HPLC system coupled on-line with an ICP-MS detector. The chromatographic separation is similar to those reported previously but with considerable gain in terms of time and sample requirement. Reproducibility is acceptable for most species. Using our method, we were able to find species-specific differences between different commercially available trace element reference materials. Because the method chosen to collect blood might interfere with speciation, the proposed methodology was used to compare heparinized plasma, ethylenediaminetetraacetic acid (EDTA) plasma, and serum from adult healthy volunteers. As expected, EDTA strongly affects speciation analysis (especially for Fe and $\mathrm{Zn}$ ), whereas changes due to the use of lithium-heparin ( $\mathrm{Li}-\mathrm{He}$ ) as anticoagulant appear to be minimized.
\end{abstract}

(c) 2011 Elsevier Inc. All rights reserved.
Speciation analysis of essential trace elements in human serum or plasma provides important information on nutritional status and homeostatic mechanisms regulating transport processes, acute phase reactions, and protection against oxidative damage $[1,2]$. Hence, obtaining quantitative speciation data on essential trace elements in human biological samples is relevant for both clinical and nutritional research. Because up to now there is no simple "speciation analyzer," appropriate separation and detection methods need to be combined and modified according to specific speciation problems [3]. High-performance liquid chromatography $(\mathrm{HPLC})^{1}$ combined with inductively coupled plasma mass spectrometry (ICP-MS) has proved to be a useful tool in speciation analysis of trace elements in human serum or [4].

\footnotetext{
* Corresponding author. Fax: +39 071206791

E-mail address: m.malavolta@inrca.it (M. Malavolta).

1 Abbreviations used: HPLC, high-performance liquid chromatography; ICP-MS, inductively coupled plasma mass spectrometry; SEC, size exclusion chromatography; EDTA, ethylenediaminetetraacetic acid; SAX, strong anion exchange; CCT, collision cell technology; KED, kinetic energy discrimination; Tris, tris(hydroxymethyl) aminomethane; Seronorm L1, Seronorm Trace element serum level 1; Seronorm L2, Seronorm Trace element serum level 2; Li-He, lithium-heparin; PAN, peak area normalization; CC, calibration curves; RSD, relative standard deviation.
}

This kind of application can be easily carried out by connecting the exit of an analytical or capillary HPLC column to the entrance of the ICP-MS nebulizer. To minimize modification of the original species, the choice of chromatographic separation is restricted to ion exchange and size exclusion chromatography (SEC) using aqueous mobile phases buffered at physiological pH. SEC offers considerable advantage in estimating the molecular weight distribution of the species present in biological samples and in quantification because of a stable baseline and good recovery $[5,6]$. This approach has been recently used to investigate the permeability of the blood-cerebrospinal fluid barrier for selected metals ( $\mathrm{Mn}, \mathrm{Fe}, \mathrm{Cu}$, $\mathrm{Zn}, \mathrm{Mg}$ and $\mathrm{Ca}$ ) by studying their speciation in paired human serum and cerebrospinal fluid samples [7]. However, SEC separation of element species from biological samples is generally unsatisfactory [4], and the time required for each chromatographic run is relatively long when also taking into account the necessity to wash the column, after each run, with acidic solutions [7] or ethylenediaminetetraacetic acid (EDTA) [8].

Although information on molecular weight distribution is lost, strong anion exchange (SAX) can provide better separations of human serum proteins than SEC [9]. The main limitation of this technique, the requirement of high salt concentrations that could 
compromise ICP-MS performance, has been solved with the use of ammonium acetate buffers without affecting chromatographic separation [10]. Indeed, fine detection of transferrin isoforms in human serum can successfully be carried out with a gradient of ammonium acetate from 0 to $250 \mathrm{mM}$ in $45 \mathrm{~min}$ on a Mono-Q HR 5/5 anion exchange column [11]. A similar approach using a linear gradient of ammonium acetate has been used to obtain quantitative speciation of the most important trace elements in human serum $[10,12,13]$. The detection of quantitative and qualitative differences in Fe speciation of sera from healthy individuals versus patients on hemodialysis suggests that speciation of human serum by SAX-ICP-MS has the potential to be translated into clinical research [10].

However, operation with this technique requires extended optimizations, time-consuming elaboration of data, and commercially available isotope-labeled spike compounds, as in the case of post-column isotope dilution analysis [10]. This might limit its application in large multicenter projects, where the use of biological material needs to be minimized, as well as in studies with laboratory mice that require repetitive survival bleeding. Here we describe a fast and quantitative HPLC-ICP-MS methodology that can be applied to carry out the speciation of $\mathrm{Fe}, \mathrm{Zn}, \mathrm{Cu}$, and $\mathrm{Se}$ in as little as $1 \mathrm{ml}$ of human plasma or serum without isotope dilution. The method employs monolithic SAX micro columns (Dionex ProSwift SAX1-S, $1 \times 50 \mathrm{~mm}$ i.d.) installed on a tandem HPLC system for off-line column wash and reequilibration. Because biobanks have usually limited amount of biological material collected with different anticoagulants, which in turn might affect speciation of trace elements [14], the proposed methodology has been used to compare speciation of $\mathrm{Fe}, \mathrm{Cu}, \mathrm{Zn}$, and Se in serum, heparinized plasma, and EDTA-treated plasma samples collected from adult healthy human volunteers. The method was also used to compare speciation in different Seronorm reference materials (level 1 vs. level 2) in order to identify the presence of species-specific differences.

\section{Materials and methods}

\section{Instrumentation}

The LC system used for the separation of serum proteins consisted of a Biocompatible Dionex Ultimate 3000 Titanium System (Dionex, USA) equipped with an FLM-3200 Flow Manager, a DGP3600MB Dual Ternary Low-Pressure Proportioning Micro Pump System, and a WPS-3000TBPL Capillary Autosampler (Dionex) fitted with a 1-ml loop. The temperature of the autosampler was set at $4{ }^{\circ} \mathrm{C}$ during batch analysis, and the column oven was kept at $30^{\circ} \mathrm{C}$. The system was set in tandem LC mode with off-line column regeneration. This configuration uses two identical columns that are switched (through the flow manager valve) back and forth between two flow paths, an analysis flow path and a regeneration flow path, thereby allowing column wash and reequilibration offline. While one column is equilibrated, the system injects the next sample onto the other column, thereby shortening the analysis time required to wash and equilibrate a column for the next injection. Monolithic anion exchange micro columns (Dionex ProSwift SAX1-S, $1 \times 50 \mathrm{~mm}$ i.d.) were employed in the tandem LC system for the separation of proteins.

The ICP-MS system used for detection and quantification of trace elements was a Thermo X II Series (Thermo Fischer, USA) equipped with a low-volume Cinnabar Cyclonic spray chamber (Glass Expansion, Melbourne, Australia) working at room temperature and a single piece quartz torch ( $1.5 \mathrm{~mm}$ i.d. injector) together with Xs interface cones and MicroMist U-Series $(0.2-0.6 \mathrm{ml} / \mathrm{min})$ Nebulizer (Glass Expansion). The instrument was calibrated daily with oxide and doubly charged ions set below $3 \%$.
For speciation analysis, the interface between the LC system and the ICP-MS device for automated run and acquisition of chromatograms was performed with an external trigger card included in an LC coupling kit (Thermo Fischer). Collision cell technology (CCT) without kinetic energy discrimination (KED) with a gas mixture containing $8 \% \mathrm{H}_{2}$ in He was used for speciation analysis.

For analysis of total metal content, the ICP-MS device was fitted with a Cetac-ASX 100 autosampler (CETAC Technologies, Omaha, NE, USA) and configured for CCT-KED with the same gas mixture used for speciation analysis. Operating conditions for speciation analysis and total metal contents are reported in Table 1.

\section{Reagents and materials}

The following reagents were used for the preparation of the mobile phase: tris(hydroxymethyl) aminomethane (Tris, Fluka, Sigma-Aldrich, Milano, Italy) and ammonium acetate (Fractopure, Merck, Darmstadt, Germany). Solutions were prepared with ultrapure water (Milli-Q). Stock solutions (2 M) of all these compounds were purified before use by passing through a column packed with chelating resin Chelex 100 (Merck) in $\mathrm{NH}_{4}^{+}$form. Multielement calibration solutions containing $\mathrm{Fe}, \mathrm{Zn}, \mathrm{Cu}$, and Se (blank and 0.5$100 \mathrm{ppb}$ ) were prepared by serial dilution of a parent multielement solution (Inorganic Ventures, Christiansburg, VA, USA). Triton X100 (VWR International S.R.L., Milano, Italy), Trace Select Ultra $\mathrm{HNO}_{3}$ (Sigma-Aldrich, Steinheim, Germany), and Rh (10 ppb) prepared from a parent (1000 ppb) ultrapure solution (Inorganic Ventures) were used in the makeup solution for speciation analysis and in the diluents for total element analysis. Human serum albumin, holo-transferrin, and ceruloplasmin protein standards were purchased from Sigma-Aldrich. Seronorm trace element serum level 1 (Seronorm L1, lot 0608414) and level 2 (Seronorm L2, lot N00371z) were purchased from Sero (Billingstad, Norway).

\section{Human plasma and serum samples}

Serum and plasma EDTA and lipid-heparin ( $\mathrm{Li}-\mathrm{He}$ ) plasma were obtained from healthy adult donors ( 6 males and 6 females, age range $=25-58$ years). All samples used for comparison of speciation analysis in human plasma and serum were obtained from the same donors at the same time. Serum and plasma samples were subjected to routine diagnostic tests to ensure the optimal health status of the donors, and aliquots for speciation analysis and trace elements investigations were stored at $-80^{\circ} \mathrm{C}$ until use. All donors gave written informed consent to the use of their samples for scientific investigations.

\section{Determination of total metal contents in human plasma and serum}

Serum and plasma $\mathrm{Fe}, \mathrm{Zn}, \mathrm{Cu}$, and Se were determined by a Thermo XII Series ICP-MS device (Thermo Electron, Waltham, MA, USA) by adapting methods used for direct measurement of trace elements in human blood, serum, or plasma with slight modifications [15-17]. Serum and plasma samples were centrifuged at $20,000 \mathrm{~g}$ for $10 \mathrm{~min}$, and the supernatants were diluted 1:20 (total volume $1 \mathrm{ml}$ ) with a diluent containing $0.1 \%$ Triton $\mathrm{X}-100$ (BDH Chemicals), $0.1 \%$ Trace Select Ultra $\mathrm{HNO}_{3}$ (Sigma-Aldrich), and $10 \mathrm{ppb}$ Rh (Merck) as internal standard. External multielement calibration solutions containing $\mathrm{Fe}, \mathrm{Zn}, \mathrm{Cu}$, and Se (blank and $0.5-500 \mathrm{ppb}$ ) were prepared by serial dilution of a parent multielement solution (Inorganic Ventures) using the same diluent used for the samples. Data (three repeats per sample) were acquired for ${ }^{56} \mathrm{Fe},{ }^{64} \mathrm{Zn},{ }^{63} \mathrm{Cu}$, and ${ }^{80} \mathrm{Se}$. Sample uptake was optimized at $14 \mathrm{rpm}(\sim 0.4 \mathrm{ml} / \mathrm{min})$ for $90 \mathrm{~s}$ and wash time at $60 \mathrm{~s}$ (wash solution was $1 \%$ Triton $\mathrm{X}-100$ and $0.1 \% \mathrm{HNO}_{3}$ ). Accuracy of the system 
Table 1

Instrumental parameters used on the ICP-MS device (Thermo X II Series).

\begin{tabular}{|c|c|c|}
\hline & Speciation analysis & $\begin{array}{l}\text { Total metal } \\
\text { contents }\end{array}$ \\
\hline \multicolumn{3}{|l|}{ Plasma Parameters } \\
\hline$R_{\mathrm{f}}$ power & 1250 & 1250 \\
\hline $\begin{array}{l}\text { Carrier gas flow rate } \\
\left(\mathrm{L} \mathrm{min}^{-1}\right)\end{array}$ & 0.84 & 0.78 \\
\hline $\begin{array}{l}\text { Plasma flow rate } \\
\left(\mathrm{L} \mathrm{min}^{-1}\right)\end{array}$ & 14.27 & 13.00 \\
\hline $\begin{array}{l}\text { Auxiliary gas flow rate } \\
\left(\mathrm{L} \mathrm{min}^{-1}\right)\end{array}$ & 1.02 & 0.80 \\
\hline \multicolumn{3}{|c|}{ Reaction/collision cell parameters } \\
\hline Configuration & $\mathrm{CCT}$ & CCT-KED \\
\hline CCT gas flow & 6 & 6 \\
\hline Focus & 0.39 & 0 \\
\hline Pole bias & -11.3 & -9.5 \\
\hline Hexapole bias & -5 & -10 \\
\hline \multicolumn{3}{|l|}{ Data acquisition parameters } \\
\hline Dwell time $(\mathrm{s})$ & 10 & 20 \\
\hline Repeat (times) & 1 & 3 \\
\hline Acquisition mode & $\begin{array}{l}\text { Transient (time-resolved } \\
\text { analysis) }\end{array}$ & Continuous \\
\hline Monitored isotopes & $\begin{array}{l}{ }^{54} \mathrm{Fe},{ }^{65} \mathrm{Cu},{ }^{66} \mathrm{Zn},{ }^{78} \mathrm{Se}, \\
\left({ }^{56} \mathrm{Fe},{ }^{63} \mathrm{Cu},{ }^{64} \mathrm{Zn},{ }^{68} \mathrm{Zn},\right. \\
\left.{ }^{80} \mathrm{Se}\right),{ }^{\mathrm{a}}{ }^{103} \mathrm{Rh}\end{array}$ & $\begin{array}{l}{ }^{56} \mathrm{Fe},{ }^{63} \mathrm{Cu},{ }^{64} \mathrm{Zn}, \\
{ }^{80} \mathrm{Se},{ }^{103} \mathrm{Rh}\end{array}$ \\
\hline $\begin{array}{l}\text { Peristaltic pump (ml/ } \\
\text { min) }\end{array}$ & 0.1 & 0.4 \\
\hline
\end{tabular}

Note. CCT, cell collision technology; CCT-KED, cell collision technology with kinetic energy discrimination.

a Monitored only during preliminary selection of isotopes for speciation analysis.

was routinely checked with quality control samples prepared from Seronorm L1 and L2 (Sero).

\section{Anion exchange HPLC coupled to ICP-MS}

To avoid sample manipulations that might affect speciation, the samples were injected directly into the column with no dilution. The buffers used for the chromatographic separation were $10 \mathrm{mM}$ Tris ( $\mathrm{pH}$ 7.4) (buffer A) and $1 \mathrm{M}$ ammonium acetate in 10 mM Tris (pH 7.4) (buffer B).

The HPLC separation of metal species was optimized at a flow rate of $0.2 \mathrm{ml} / \mathrm{min}$ and linearly increasing the concentration of buffer B from $0 \%$ (100\% buffer A) to 60\% (40\% buffer A) in $10 \mathrm{~min}$ ("elution program").

A tandem LC mode was used to save the time needed for washing and regenerating the columns after each run. In tandem LC mode, two identical columns are switched between two flow paths: an analysis flow path and a regeneration flow path to allow column washing and reequilibration off-line. While one column is equilibrated, the system injects the next sample on the other. The program used to wash and regenerate the columns off-line was the following: $60 \%$ B to $100 \%$ B in $0.5 \mathrm{~min}$, hold $4 \mathrm{~min}$, return to $0 \% \mathrm{~B}$ in $0.5 \mathrm{~min}$, and equilibrate with $0 \% \mathrm{~B}$ for $5 \mathrm{~min}$.

The quantification of peaks was evaluated with the following two methods: peak area normalization (PAN) and absolute quantification by calibration curves (CC). The PAN method comprised the normalization of peak areas and comparison of the relative areas of individual peaks with the total amount of element obtained by a separate ICP-MS measurement. This quantification method has been proved to give similar results to those obtained with isotope dilution using anion exchange coupled to ICP-MS [12]. To compensate time-dependent nonspectral interferences due to the increasing ammonium salt concentration in the mobile phase, the signals were normalized for the time slice internal standard (Rh, $10 \mathrm{ppb}$ ) and mixed in the column eluate by post-column dilution with $0.3 \% \mathrm{HNO}_{3}$ at $0.1 \mathrm{ml} / \mathrm{min}$.
The CC method consisted of the absolute quantification using calibration curves obtained by running blanks in the HPLC system while performing post-column dilution with calibration standards of increasing element concentration $\left(0.3 \% \mathrm{HNO}_{3}\right.$ with $10 \mathrm{ppb} \mathrm{Rh}$ and $0,0.5,1,5,10$, and $20 \mathrm{ppb}$ of $\mathrm{Fe}, \mathrm{Cu}, \mathrm{Zn}$, and Se). The chromatograms obtained replacing the post-column dilution with the calibration standards consisted of simple baseline chromatograms with increasing height from the time axis (see a representative example for Se in Fig. 1). Areas from the calibration standard chromatograms were defined from each element profile on the basis of the eluting time of the sample peaks and integrated to obtain a calibration curve of area versus "element amount." The element amounts corresponding to a specific area were calculated by multiplication of the element mass flow (calculated by multiplication of the concentration of the element in the calibration standards for the flow rate of the makeup solution) for the time used to define these areas. Calibration curves for each peak (areas vs. element amount) were than constructed to quantify the unknown peak areas of the samples (Fig. 1). The flow rate of the post-column dilution was maintained at $0.1 \mathrm{ml} / \mathrm{min}$, measured and calibrated daily in the peristaltic pump. For peak integration and quantification, the intensities of all monitored isotopes were normalized to ${ }^{103} \mathrm{Rh}$ as internal standard.

\section{Results}

\section{Selection of isotopes for speciation analysis}

The conditions (CCT-KED) and isotopes $\left({ }^{56} \mathrm{Fe},{ }^{63} \mathrm{Cu},{ }^{64} \mathrm{Zn}\right.$, and ${ }^{80} \mathrm{Se}$ ) used for total trace element analysis were also tested for speciation with SAX-ICP-MS. When the ICP-MS device was operated in these conditions, Se detection and quantification (whichever isotope was selected) was scarcely distinguishable from the baseline (data not shown). This problem disappeared when operating in CCT conditions without KED (Table 1); thus, this configuration was chosen for speciation analysis. Using the latter conditions, the selection of proper isotopes may be of great importance because polyatomic interferences due to matrix elements (e.g., S, $\mathrm{P}, \mathrm{Cl}, \mathrm{Br}$ ), oxygen, hydrogen, and argon might not be completely removed.

A preliminary analysis of Seronorm L1 and L2 was performed to choose the less interfered isotopes for speciation analysis. Isotope ratios in each detectable peak of the chromatogram were calculated for the most abundant isotopes of each element ${ }^{56} \mathrm{Fe} /{ }^{54} \mathrm{Fe}$, ${ }^{63} \mathrm{Cu} /{ }^{65} \mathrm{Cu},{ }^{64} \mathrm{Zn} /{ }^{66} \mathrm{Zn},{ }^{68} \mathrm{Zn} /{ }^{66} \mathrm{Zn}$, and ${ }^{80} \mathrm{Se} /{ }^{78} \mathrm{Se}$. These values were compared with the respective ratios calculated from the natural abundance of the isotopes. Isotope ratios, expressed as percentages of the theoretical isotope ratio, changed according to retention time with the following ranges: 108.7 to $125.74 \%$ for ${ }^{56} \mathrm{Fe} /{ }^{54} \mathrm{Fe}$, 99.8 to $100.5 \%$ for ${ }^{63} \mathrm{Cu} /{ }^{65} \mathrm{Cu}, 101.5$ to $104.2 \%$ for ${ }^{64} \mathrm{Zn} /{ }^{66} \mathrm{Zn}, 107.3$ to $110.6 \%$ for ${ }^{68} \mathrm{Zn} /{ }^{66} \mathrm{Zn}$, and 111.3 to $112.1 \%$ for ${ }^{80} \mathrm{Se} /{ }^{78} \mathrm{Se}$. The observed data of isotopes ratio were corrected for the mass bias using a well-known linear model [18]. To minimize interferences, those isotopes were selected for quantitative evaluation, which provided the lower element content (the denominator in each isotope ratio reported above) because the more interfered isotope is expected to result in an incorrectly higher metal content. On the basis of these preliminary results, the following isotopes were monitored in each chromatographic run: ${ }^{54} \mathrm{Fe},{ }^{65} \mathrm{Cu},{ }^{66} \mathrm{Zn}$, and ${ }^{78} \mathrm{Se}$.

\section{Chromatographic separation}

Fig. 2 shows a representative example of a chromatographic separation obtained after injection of $1 \mathrm{ml}$ of human serum obtained from a healthy young donor. 

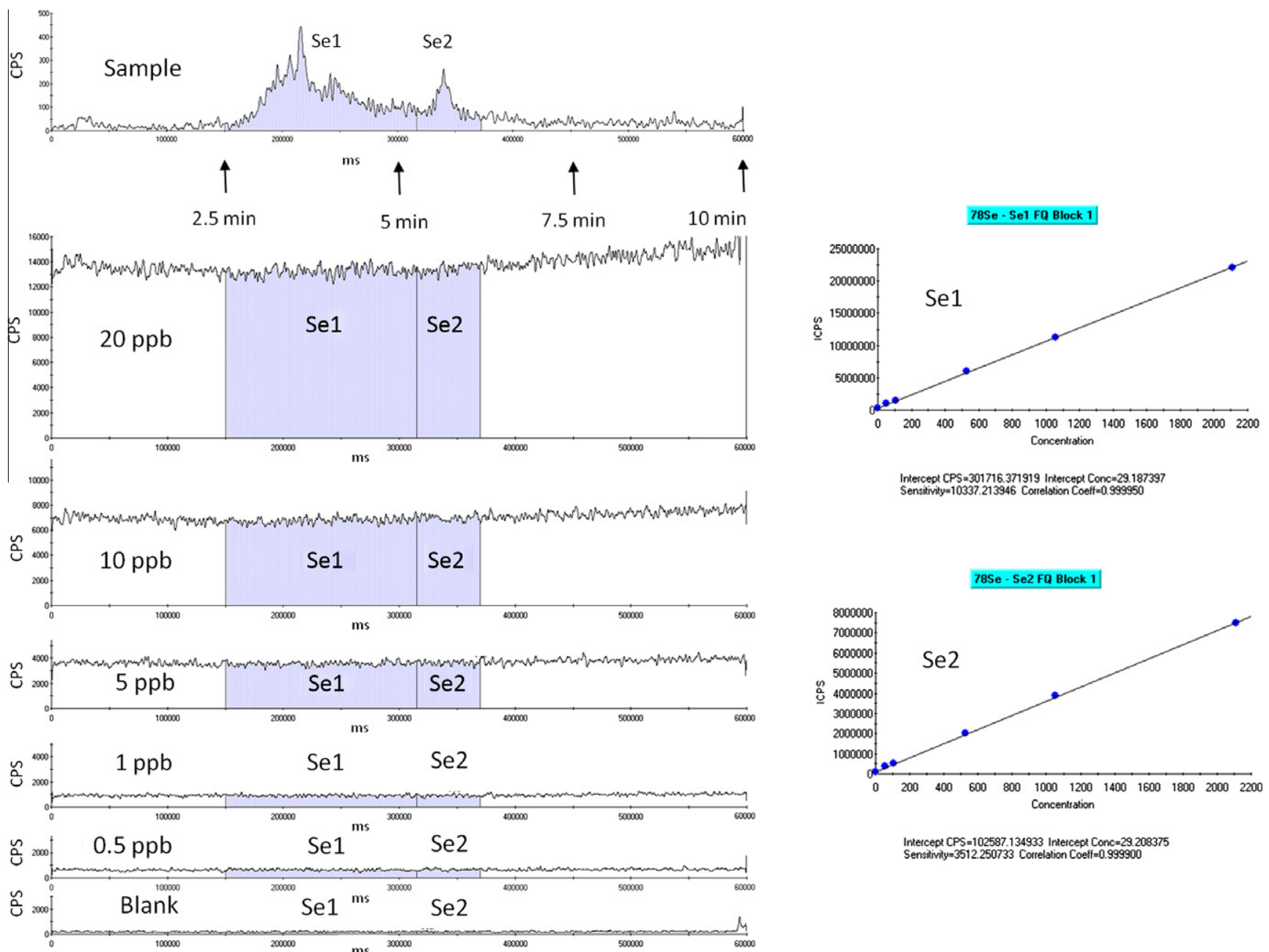
Intercept CPS $=102587.134933$ Intelcepl Conc $=29.2083$

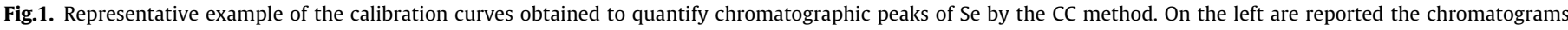

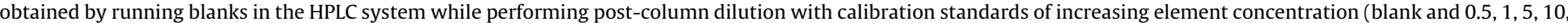

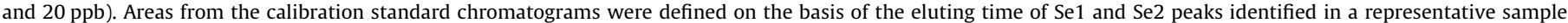
chromatogram (top chromatogram on the left). The respective calibration curves for Se1 and Se2 are reported on the right of the figure. CPS, counts per second.

Although elution conditions were three to six times faster when compared with previously published chromatograms $[10,12]$, the resolution of element species is perfectly retained. Fe is eluted in a main fraction (Fe1) ( after $2.5 \mathrm{~min}$ ) followed by a broad peak starting at $3.7 \mathrm{~min}(\mathrm{Fe} 2)$. The retention time of the main fraction Fe1 corresponded to the retention time of a purified human holo-transferrin standard. Fe1 is composed of at least two subpeaks (Fe1a and Fe1b) that are only partially resolved with the current chromatographic conditions. $\mathrm{Fe} 2$ is also composed of at least two sub-peaks ( $\mathrm{Fe} 2 \mathrm{a}$ and $\mathrm{Fe} 2 \mathrm{~b}$ ) that cannot be completely resolved due to their broadness. $\mathrm{Cu}$ is eluted into three fractions: a small peak (Cu1) eluting after $3.5 \mathrm{~min}$, an intermediate fraction (Cu2) composed of two subpeaks ( $\mathrm{Cu} 2 \mathrm{a}$ and $\mathrm{Cu} 2 \mathrm{~b}$ ), and a main fraction (Cu3) eluting at 7.5 min composed of a large peak (Cu3a) and a small shoulder ( $\mathrm{Cu} 3 \mathrm{~b})$ mostly hidden by the tail of $\mathrm{Cu} 3 \mathrm{a}$. The retention time of the main fraction $\mathrm{Cu} 3$ corresponded to the retention time of a purified human ceruloplasmin standard. Zn eluted mainly in a large fraction $(\mathrm{Zn} 1)$ from 0.7 to $5.8 \mathrm{~min}$, with a second small fraction (Zn2) eluting with the same time of Cu3a. $\mathrm{Zn} 1$ was composed of two or more subpeaks ( $\mathrm{Zn} 1 \mathrm{a}$ and $\mathrm{Zn} 1 \mathrm{~b}$ ). The retention time of $\mathrm{Zn} 1 \mathrm{a}$ was consistent with the void volume given that we were not able to find any substance eluting before this time. However, the nature of this peak was not consistent with the presence of free $\mathrm{Zn}^{2+}$ given that injection of $\mathrm{Zn}\left(\mathrm{NO}_{3}\right)_{2}$ led to a wide-shaped peak that started eluting after 1.5 min. The injection of human standard albumin yielded two peaks with the same retention time of $\mathrm{Zn} 1 \mathrm{a}$ and $\mathrm{Zn} 1 \mathrm{~b}$. Moreover, the proportion of the peaks (between $\mathrm{Zn} 1 \mathrm{a}$ and $\mathrm{Zn} 1 \mathrm{~b}$ ) was found to be not reproducible (data not shown). For all of these reasons, we considered $\mathrm{Zn} 1 \mathrm{a}$ and $\mathrm{Zn} 1 \mathrm{~b}$ as being part of a single large peak ( $\mathrm{Zn} 1)$.

The main fraction of Se (Se1) eluted after $2.5 \mathrm{~min}$, with a second small peak (Se2) eluting at 5.3 min (Fig. 2). Injection of inorganic selenium yielded a peak with approximately the retention time of Se2. Se1 appears to be composed of at least a large peak (Se1a) and a second group of very small peaks (Se1b) scarcely resolved by the system.

\section{Quantification of individual element species}

Quantification of element species for SAX-ICP-MS was performed by two methods. The first method comprised PAN and comparison of the relative areas of individual peaks with the total amount of element in the injected portion of the sample. Total element concentrations used for the PAN method were calculated by separate ICP-MS analysis (Table 2).

Elemental concentrations calculated by ICP-MS were found to be within the accepted range for all elements with the sole exception of Se, which was found to be higher than $20 \%$ of the declared 

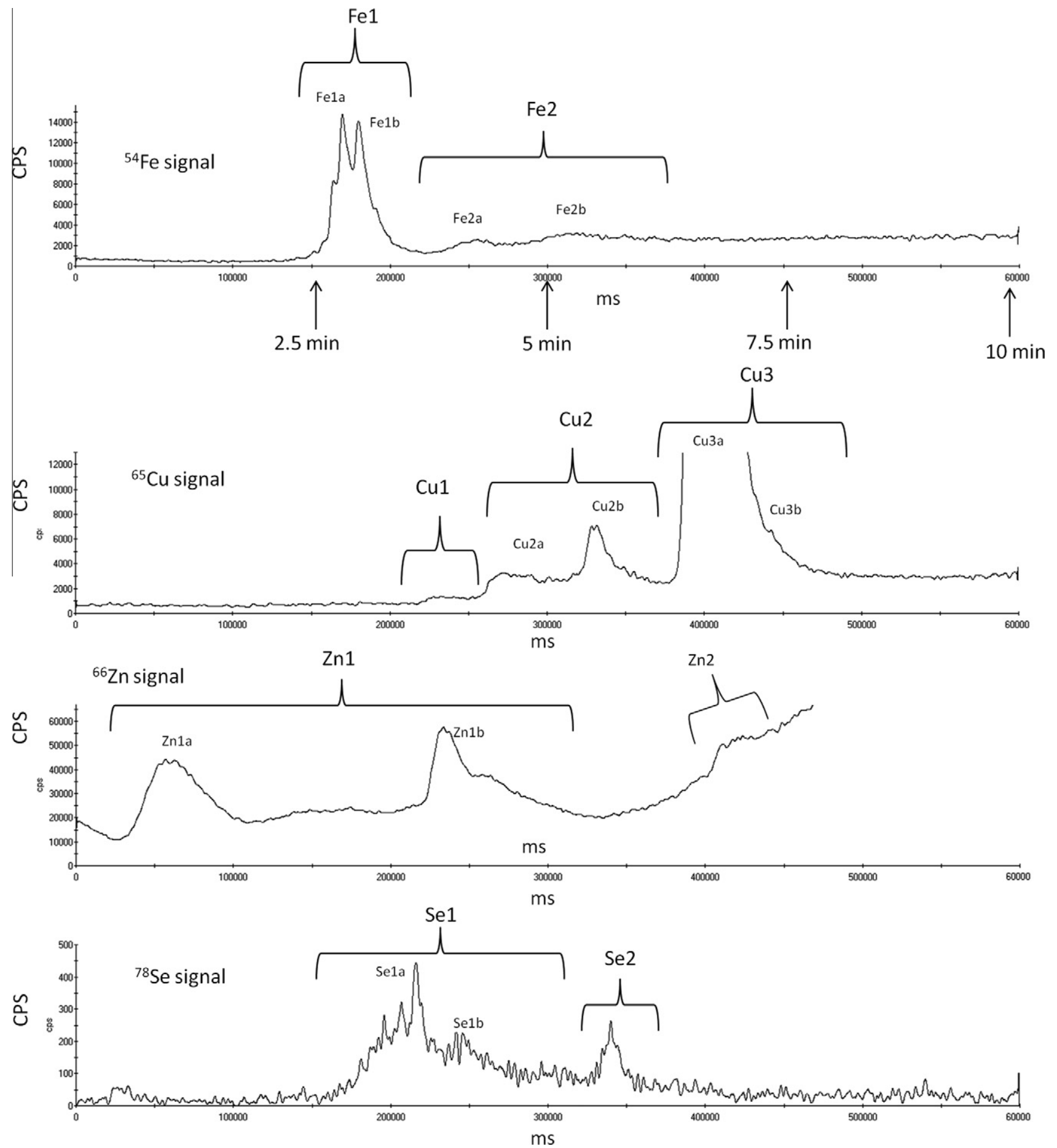

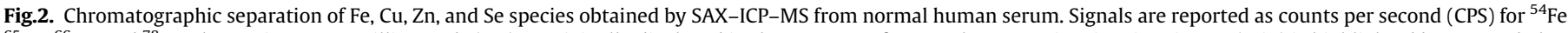

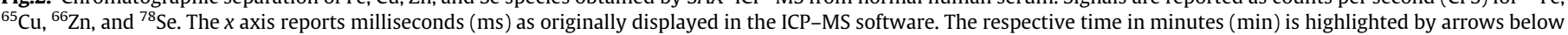
the chromatogram of the ${ }^{54} \mathrm{Fe}$ signal.

values. However, taking into account that increased concentration of Se in Seronorm has been previously observed by others [19], we considered our measurements to be sufficiently accurate for use in the calculation of species concentrations with the PAN method.

The second method consisted of the use of CC constructed integrating the signals obtained with post-column dilution standards over the time period defined for each peak in the chromatogram (see the representative example for Se in Fig. 1). This approach was also used to estimate the limit of detection of our system after consideration of the post-column dilution factor.

\section{Limit of detection in post-column calibration}

Limits of detection estimated with the post-column calibration were $1 \mathrm{ppb}$ for ${ }^{54} \mathrm{Fe}, 0.5 \mathrm{ppb}$ for ${ }^{65} \mathrm{Cu}, 5 \mathrm{ppb}$ for ${ }^{66} \mathrm{Zn}$, and $0.2 \mathrm{ppb}$ for ${ }^{78} \mathrm{Se}$. These limits of detection refer to the metal concentrations in the eluates.

Limits of detection for peaks in chromatograms

Limits of detection for each specific element peak were in some cases dependent on the retention time. The limits of detection 
Table 2

Total element concentration of Seronorm reference material measured by ICP-MS in short- and long-term analysis.

\begin{tabular}{|c|c|c|c|c|c|}
\hline & \multirow[t]{2}{*}{ Element } & \multicolumn{2}{|c|}{ Declared values } & \multirow{2}{*}{$\begin{array}{l}\text { Short-term measurement }^{\mathrm{a}} \\
\text { (mean } \pm \mathrm{RSD} \% \text { ) }\end{array}$} & \multirow{2}{*}{$\begin{array}{l}\text { Long-term measurement } \\
(\text { mean } \pm \text { RSD } \%)\end{array}$} \\
\hline & & Mean & Uncertainty & & \\
\hline \multirow[t]{4}{*}{ Seronorm L1 } & $\mathrm{Fe}$ & 1200 & $1000-1400$ & $1330 \pm 1$ & $1335 \pm 3$ \\
\hline & $\mathrm{Cu}$ & 1170 & $1010-1330$ & $1060 \pm 1$ & $1063 \pm 4$ \\
\hline & $\mathrm{Zn}$ & 1220 & $1100-1340$ & $1150 \pm 2$ & $1150 \pm 6$ \\
\hline & Se & 59 & $53-65$ & $75 \pm 2$ & $77 \pm 3$ \\
\hline \multirow[t]{4}{*}{ Seronorm L2 } & $\mathrm{Fe}$ & 1910 & 1790-2030 & $1907 \pm 2$ & $1913 \pm 4$ \\
\hline & $\mathrm{Cu}$ & 2600 & $2400-2800$ & $2601 \pm 2$ & $2611 \pm 7$ \\
\hline & $\mathrm{Zn}$ & 920 & $850-980$ & $919 \pm 3$ & $919 \pm 7$ \\
\hline & $\mathrm{Se}$ & 136 & $127-145$ & $166 \pm 3$ & $167 \pm 4$ \\
\hline
\end{tabular}

a Calculated by triplicate ICP-MS analysis performed within the same day.

b Calculated by triplicate ICP-MS analysis performed twice a week for 2 months.

were calculated as $3 * \mathrm{SD}_{0}$ (where $\mathrm{SD}_{0}$ is the value of the standard deviation as the concentration of the analyte approaches 0 ) from a plot of standard deviation ( $y$ axis) versus concentration ( $x$ axis) in which four concentrations of Seronorm L2 (diluted 1:2, 1:4, 1:8, and 1:10 with buffer A) were analyzed five times. These limits were the following: $12 \mathrm{ppb}$ for Fe1, $18 \mathrm{ppb}$ for Fe2, $18 \mathrm{ppb}$ for $\mathrm{Cu} 1,15 \mathrm{ppb}$ for $\mathrm{Cu} 2,15 \mathrm{ppb}$ for $\mathrm{Cu} 3,36 \mathrm{ppb}$ for $\mathrm{Zn} 1,36 \mathrm{ppb}$ for Zn2, 2 ppb for Se1, and 2 ppb for Se2.

\section{Variability of quantification}

To examine the variability of quantitative results obtained with both methods as well as the recovery of quantitative results obtained with the CC method, Seronorm L1 and Seronorm L2 were analyzed in the long term ( 2 samples per week for 2 months, $n=8$ replicates per sample) and the short term ( 2 samples within the same day, $n=5$ replicates per sample) using both methods.

The relative standard deviations (RSDs) for replicate measurements of $\mathrm{Fe}, \mathrm{Cu}$, and Se species performed within the same day (short term) were comprised within ranges of 2 to $34 \%$ and 5 to $68 \%$ by the PAN and CC methods, respectively (Table 3 ). The RSDs of element species in long-term analysis were comprised within ranges of 4 to $50 \%$ and 9 to $74 \%$ by the PAN and CC methods, respectively (Table 4). Comparison of $\mathrm{Zn}$ species was not performed because of the very low amount of $\mathrm{Zn} 2$ in Seronorm samples (usually below threshold of detection) (see Fig. 2) and of the poor reproducibility of the remaining $\mathrm{Zn}$ peaks (data not shown).

\section{Recovery by CC method}

The recovery for the $\mathrm{CC}$ method was calculated as a ratio between the sum of all element species and the total concentration of the same element calculated by separate ICP-MS analysis.

Tables 3 and 4 show that the recovery for Fe and $\mathrm{Cu}$ is slightly higher than the total element concentration measured by ICP-MS in both long- and short-term analysis.

\section{Comparison between Seronorm L1 and Seronorm L2}

The RSDs of each element species found in Seronorm L1 and Seronorm L2 increased from short- to long-term analysis, but precision for most elements remained acceptable (RSD < 20\%) (Tables 3 and 4).

As expected by the values reported in the respective data sheets, the total amount of $\mathrm{Fe}, \mathrm{Cu}$, and Se was found to be different between Seronorm L1 and Seronorm L2. Speciation analysis shows that these differences were mostly or exclusively due to $\mathrm{Fe} 1, \mathrm{Cu} 2$, and Se1. The most representative example is the sixfold higher levels of $\mathrm{Cu} 2$ in Seronorm L2 when compared with the respective amount found in Seronorm L1. Representative chromatograms illustrating the most important species-specific differences between Seronorm L1 and Seronorm L2 are reported in Fig. 3.
Comparison of speciation analysis in serum, heparin plasma, and EDTA plasma

Taking into account that EDTA can introduce metal contaminations from the HPLC flow pathway and can interfere with $\mathrm{Fe}, \mathrm{Cu}$, and $\mathrm{Zn}$ quantification by the PAN method, quantitative results were calculated by the CC method. Quantitative comparison of all element species obtained from human serum, EDTA plasma, and $\mathrm{Li}-\mathrm{He}$ plasma are reported in Table 5 . $\mathrm{Li}-\mathrm{He}$ and serum display similar peaks in each profile, whereas EDTA plasma profiles show considerable alterations and contaminations (Fig. 4). For example, Fe species obtained from EDTA plasma display a reduction of Fe1 and an abnormal increase of the signal in correspondence of Fe2 when compared with serum and Li-He profiles (Fig. 4A). The chromatographic profile of $\mathrm{Cu}$ obtained from serum was also similar to that obtained from Li-He, whereas the one obtained from EDTA plasma showed contaminated peaks with the exception of $\mathrm{Cu} 3$ (Fig. 4B). Indeed, although a slight time shift was detected in the EDTA plasma chromatogram for $\mathrm{Cu} 3$, quantitative data of this species were comparable independently by the anticoagulants or serum used (Table 5). Comparable results among Li-He plasma, serum, and EDTA plasma were also obtained for Se peaks, whereas completely altered results were obtained for Zn measured in EDTA plasma samples with respect to serum and $\mathrm{Li}-\mathrm{He}$ plasma samples (Table 5).

\section{Discussion}

The development of trace metal speciation in biological materials is approaching application in large multicenter projects. Overcoming the problems related to the relative high costs and time of analysis while minimizing the amount of sample required for performing the analysis would greatly increase the applications of this technique.

In this work, a semi-micro SAX-ICP-MS method for fast speciation of essential trace elements in $1 \mathrm{ml}$ of human serum or plasma has been described. Although the recoveries for $\mathrm{Fe}$ and $\mathrm{Cu}$ appear to be slightly overestimated (119 and $124 \%$, respectively), the current method can easily detect qualitative and quantitative differences between human serum reference samples (Seronorm L1 vs. Seronorm L2). Chromatograms and quantitative data can be obtained from $1 \mathrm{ml}$ of biological material in less than $10 \mathrm{~min}$ without waiting for column wash and regeneration after each run. Notably, a similar speciation analysis of $\mathrm{Zn}, \mathrm{Cu}, \mathrm{Fe}$, and $\mathrm{Se}$ in human serum has been achieved by others using $100 \mathrm{ml}$ of biological material in a time ranging from $25 \mathrm{~min} \mathrm{[10]} \mathrm{up} \mathrm{to} 60 \mathrm{~min}$ [12], excluding the time required for column regeneration after each run. Quantification done by the PAN method, whose accuracy has been previously verified by others [12], makes the procedure very simple and considerably reduces the time required for elaboration of 
Table 3

Comparison of speciation results obtained from short-term analysis ${ }^{\mathrm{a}}$ of Seronorm L1 and Seronorm L2 calculated by PAN and CC.

\begin{tabular}{|c|c|c|c|c|c|c|c|c|c|c|c|c|c|c|c|c|c|c|c|c|}
\hline \multirow{2}{*}{$\begin{array}{l}\text { Species: } \\
\text { Method: }\end{array}$} & \multicolumn{2}{|c|}{$\begin{array}{l}\text { Fe1 } \\
\text { mean ppb } \\
(\mathrm{RSD} \%)\end{array}$} & $\begin{array}{l}\text { Fe2 } \\
\text { mean ppb } \\
(\mathrm{RSD} \%)\end{array}$ & \multirow{2}{*}{$\begin{array}{l}\text { Fe Tot }{ }^{b} \\
\text { mean } \\
\text { ppb } \\
(\text { RSD\%) } \\
\text { PAN }\end{array}$} & \multirow{2}{*}{$\begin{array}{l}\text { Fe } \text { Tot }^{\mathrm{c}} \\
\text { mean } \\
\text { ppb } \\
\text { (RSD\%) } \\
\text { CC }\end{array}$} & \multirow{2}{*}{$\begin{array}{l}\text { Fe } \\
\text { Rec\% } \\
\text { (RSD\%) } \\
\text { CC }\end{array}$} & \multirow{2}{*}{$\begin{array}{l}\text { Cu1 } \\
\text { mean } \\
\text { ppb } \\
\text { (RSD\%) } \\
\text { PAN CC }\end{array}$} & \multicolumn{2}{|c|}{$\begin{array}{l}\mathrm{Cu} 2 \\
\text { mean ppb } \\
(\mathrm{RSD} \%)\end{array}$} & \multicolumn{2}{|c|}{$\begin{array}{l}\mathrm{Cu} 3 \\
\text { mean ppb } \\
(\mathrm{RSD} \%)\end{array}$} & \multirow{2}{*}{$\begin{array}{l}\mathrm{Cu} \\
\text { Tot }^{\mathrm{b}} \\
\text { mean } \\
\text { ppb } \\
\text { (RSD\%) } \\
\text { PAN }\end{array}$} & \multirow{2}{*}{$\begin{array}{l}\mathrm{Cu} \\
\text { Tot }^{\mathrm{c}} \\
\text { mean } \\
\text { ppb } \\
\text { (RSD\%) } \\
\text { CC }\end{array}$} & \multirow{2}{*}{$\begin{array}{l}\mathrm{Cu} \\
\mathrm{Rec} \% \mathrm{~d} \\
(\mathrm{RSD} \%) \\
\mathrm{CC}\end{array}$} & \multicolumn{2}{|c|}{$\begin{array}{l}\text { Se1 } \\
\text { mean ppb } \\
(\mathrm{RSD} \%)\end{array}$} & \multirow{2}{*}{$\begin{array}{l}\text { Se2 } \\
\text { mean } \\
\text { ppb } \\
(\text { RSD\%) } \\
\text { PAN CC }\end{array}$} & \multirow{2}{*}{$\begin{array}{l}\text { Se Tot } \\
\text { mean } \\
\text { ppb } \\
\text { (RSD\%) } \\
\text { PAN }\end{array}$} & \multirow{2}{*}{$\begin{array}{l}\text { Se Tot } \\
\text { mean } \\
\text { ppb } \\
(\text { RSD\%) } \\
\text { CC }\end{array}$} & \multirow{2}{*}{$\begin{array}{l}\text { Se } \\
\text { Rec\%d } \\
(\mathrm{RSD} \%) \\
\text { CC }\end{array}$} \\
\hline & PAN & & AN CC & & & & & PAIV & & Aiv & & & & & PAN & & & & & \\
\hline L1 & (2) & & $\begin{array}{ll}274 & 363 \\
(9) & (23)\end{array}$ & $\begin{array}{l}1330 \\
(1)\end{array}$ & $(4)$ & & $\begin{array}{ll}35 & 50 \\
(30) & (68\end{array}$ & (4) & & $\begin{array}{l}777 \\
(4)\end{array}$ & & (1) & & & (4) & & $\begin{array}{ll}12 & 34 \\
(22) & (15)\end{array}$ & & & \\
\hline $\begin{array}{l}\text { eronorm } \\
\text { L2 }\end{array}$ & $\begin{array}{l}1620^{*} \\
(2)\end{array}$ & $\begin{array}{l}1788^{*} \\
(5)\end{array}$ & $\begin{array}{ll}287 & 405 \\
(10) & (27)\end{array}$ & $\begin{array}{l}1907^{*} \\
(2)\end{array}$ & $\begin{array}{l}2193^{*} \\
(8)\end{array}$ & $\begin{array}{l}115 \\
(8)\end{array}$ & $\begin{array}{ll}63^{8} & 98 \\
(18) & (40)\end{array}$ & $\begin{array}{l}1577^{*} \\
(1)\end{array}$ & $\begin{array}{l}1839^{*} \\
(12)\end{array}$ & $\begin{array}{l}961^{*} \\
(2)\end{array}$ & $\begin{array}{l}1255^{*} \\
(7)\end{array}$ & $\begin{array}{l}2601^{*} \\
(2)\end{array}$ & $\begin{array}{l}3193^{*} \\
(8)\end{array}$ & $\begin{array}{l}123 \\
(8)\end{array}$ & $149^{*}$ & $\begin{array}{l}130^{*} \\
(14)\end{array}$ & $\begin{array}{ll}17 & 32 \\
(34) & (36)\end{array}$ & $\begin{array}{l}166^{*} \\
(3)\end{array}$ & $\begin{array}{l}162^{*} \\
(16)\end{array}$ & $\begin{array}{l}98 \\
(16)\end{array}$ \\
\hline
\end{tabular}

${ }^{*} P<0.01$ compared with Seronorm L1 by paired Student's $t$ test.

$\S P<0.05$ compared with Seronorm L1 by Student's $t$ test.

a Short term = mean of $n=5$ measurements performed within the same day from the same Seronorm stock.

b Total amount calculated by a separate ICP-MS analysis performed in triplicate on the same sample.

c Tot, total amount calculated by CC as the sum of all peaks for each element.

d Rec\%, recovery percentage calculated by the ratio of sum of peaks (calculated by CC) to the respective total amount calculated by separate ICP-MS.

Table 4

Comparison of speciation results obtained from long-term analysis ${ }^{\mathrm{a}}$ of Seronorm L1 and Seronorm L2 calculated by PAN) and CC.

\begin{tabular}{|c|c|c|c|c|c|c|c|c|c|c|c|c|c|c|c|c|c|c|c|c|}
\hline \multirow{2}{*}{$\begin{array}{l}\text { Species: } \\
\text { Method: }\end{array}$} & \multicolumn{2}{|c|}{$\begin{array}{l}\text { Fe1 } \\
\text { mean ppb } \\
(\mathrm{RSD} \%)\end{array}$} & $\begin{array}{l}\text { Fe2 } \\
\text { mean ppb } \\
(\text { RSD\%) }\end{array}$ & \multirow[t]{2}{*}{$\begin{array}{l}\text { Fe Tot }{ }^{\mathrm{b}} \\
\text { mean } \\
\text { ppb } \\
\text { (RSD\%) }\end{array}$} & \multirow{2}{*}{$\begin{array}{l}\text { Fe Tot }{ }^{\mathrm{C}} \\
\text { mean } \\
\text { ppb } \\
(\mathrm{RSD} \%) \\
\text { CC }\end{array}$} & \multirow{2}{*}{$\begin{array}{l}\text { Fe } \\
\text { Rec\% }{ }^{\mathrm{d}} \\
(\mathrm{RSD} \%) \\
\mathrm{CC}\end{array}$} & \multirow{2}{*}{$\begin{array}{l}\text { Cu1 } \\
\text { mean } \\
\text { ppb } \\
(\mathrm{RSD} \%) \\
\text { PAN CC }\end{array}$} & \multicolumn{2}{|c|}{$\begin{array}{l}\text { Cu2 } \\
\text { mean } \\
\text { ppb (RSD\%) }\end{array}$} & \multicolumn{2}{|c|}{$\begin{array}{l}\text { Cu3 } \\
\text { mean ppb } \\
(\mathrm{RSD} \%)\end{array}$} & \multirow{2}{*}{$\begin{array}{l}\mathrm{Cu} \\
\text { Tot }^{\mathrm{b}} \\
\text { mean } \\
\text { ppb } \\
\text { (RSD\%) } \\
\text { PAN }\end{array}$} & \multirow{2}{*}{$\begin{array}{l}\mathrm{Cu} \\
\text { Tot }^{\mathrm{c}} \\
\text { mean } \\
\text { ppb } \\
\text { (RSD\%) } \\
\text { CC }\end{array}$} & \multirow{2}{*}{$\begin{array}{l}\mathrm{Cu} \\
\mathrm{Rec} \% \\
(\mathrm{RSD} \%)\end{array}$} & \multicolumn{2}{|c|}{$\begin{array}{l}\text { Se1 } \\
\text { mean ppb } \\
(\mathrm{RSD} \%)\end{array}$} & \multirow{2}{*}{$\begin{array}{l}\text { Se2 } \\
\text { mean } \\
\text { ppb } \\
(\text { RSD\%) } \\
\text { PAN CC }\end{array}$} & \multirow{2}{*}{$\begin{array}{l}\text { Se Tot }^{\mathrm{b}} \\
\text { mean } \\
\text { ppb } \\
\text { (RSD\%) } \\
\text { PAN }\end{array}$} & \multirow{2}{*}{$\begin{array}{l}\text { Se Tot }{ }^{\mathrm{c}} \\
\text { mean } \\
\text { ppb } \\
(\mathrm{RSD} \%) \\
\text { CC }\end{array}$} & \multirow{2}{*}{$\begin{array}{l}\text { Se } \\
\text { Rec\% }{ }^{d} \\
(\mathrm{RSD} \%) \\
\text { CC }\end{array}$} \\
\hline & & & N CC & & & & & & & & & & & & & & & & & \\
\hline $\begin{array}{r}\text { rol } \\
\text { L1 }\end{array}$ & 57 & & $\begin{array}{ll}278 & 383 \\
(25) & (25)\end{array}$ & $\begin{array}{l}1335 \\
(3)\end{array}$ & $\begin{array}{l}1588 \\
(18)\end{array}$ & & $\begin{array}{ll}33 & 48 \\
(49) & (74)\end{array}$ & $\begin{array}{l}249 \\
(17)\end{array}$ & ) & $\begin{array}{l}781 \\
(8)\end{array}$ & & $\begin{array}{l}1063 \\
(4)\end{array}$ & $\begin{array}{l}1313 \\
(18)\end{array}$ & $(2$ & $\begin{array}{l}65 \\
(9)\end{array}$ & (26) & $\begin{array}{ll}12 & 35 \\
(34) & (44\end{array}$ & & $\begin{array}{l}75 \\
(43)\end{array}$ & $\begin{array}{l}97 \\
(26)\end{array}$ \\
\hline $\begin{array}{l}\text { Seronorm } \\
\text { L2 }\end{array}$ & $\begin{array}{l}1615^{*} \\
(4)\end{array}$ & $\begin{array}{l}1720^{*} \\
(11)\end{array}$ & $\begin{array}{ll}298 & 395 \\
(20) & (33)\end{array}$ & $\begin{array}{l}1913^{*} \\
(4)\end{array}$ & $\begin{array}{l}2115^{*} \\
(12)\end{array}$ & $\begin{array}{l}111 \\
(12)\end{array}$ & $\begin{array}{ll}65^{*} & 95^{*} \\
(35) & (66)\end{array}$ & $\begin{array}{l}1583^{*} \\
(6)\end{array}$ & $\begin{array}{l}1853^{*} \\
(16)\end{array}$ & $\begin{array}{l}948^{*} \\
(8)\end{array}$ & $\begin{array}{l}1180^{*} \\
(9)\end{array}$ & $\begin{array}{l}2611^{*} \\
(7)\end{array}$ & $\begin{array}{l}3129^{*} \\
(11)\end{array}$ & $\begin{array}{l}120 \\
(11)\end{array}$ & $\begin{array}{l}154^{*} \\
(4)\end{array}$ & & $\begin{array}{ll}13 & 32 \\
(50) & (55)\end{array}$ & $\begin{array}{l}167^{*} \\
(4)\end{array}$ & & $\begin{array}{l}93 \\
(21)\end{array}$ \\
\hline
\end{tabular}

* $P<0.001$ compared with Seronorm L1 by Student's $t$ test.

a Long term = mean of $n=16$ measurements performed twice a week for 2 months from the same Seronorm stock.

b Total amount calculated by a separate ICP-MS analysis performed twice a week (for 2 months) in triplicate on the same sample.

c Tot, total amount calculated by CC as the sum of all peaks for each element.

d Rec\%, recovery\% calculated by the ratio of sum of peaks (calculated by CC) to the respective total amount calculated by separate ICP-MS.

chromatographic data. For all species, the PAN method displays lower RSDs than the CC method, thereby suggesting that the attempt to directly quantify each peak by CC might introduce additional factors increasing the variability in the measurement.

With the exception of $\mathrm{Zn}$ species, the repeatability (in both short- and long-term analysis) is also satisfactory considering the low concentration of some species, the relative breadth of some chromatographic peaks, and the low amount of sample injected $(1 \mu \mathrm{l})$. Nevertheless, it should be noted that results for Cu1 display higher variability (in both short- and long-term analysis) and could present some bias because the concentration of this species was around the limit of detection. The recovery for Fe and $\mathrm{Cu}$ obtained after quantification with the CC method suggests that even when working with biocompatible instruments, polymeric columns, and chelated eluents, residual metal contamination or interferences might not be completely removed. However, the reproducibility of quantitative data obtained by PAN in long-term analysis of Seronorm for $\mathrm{Fe}, \mathrm{Cu}$, and Se species suggests that these problems are minimized and that results remain valid at least for comparative purposes. Conversely, the poor reproducibility of measurements performed by CC compared with PAN suggests that the use of CC should be limited only to samples that can introduce contaminations within the flow path (i.e., samples containing high amounts of metal chelators such as EDTA plasma). Another problem involves the speciation of $\mathrm{Zn}$ that was found to be poorly reproducible. These problems may arise from interaction of $\mathrm{Zn}$ species with the stationary phase of the column or from the large amount of albumin (the most important carrier of $\mathrm{Zn}$ and the most abundant protein in serum) in the undiluted serum samples. Moreover, we observed a gradual increase of the $\mathrm{Zn}$ baseline with increasing ammonium acetate concentration (Fig. 2). Extensive wash of the column with $\mathrm{HCl}$ (and subsequent recondition with the elution buffers) attenuated this phenomenon. However, this procedure led to a marked negative recovery of the subsequent injected samples (data not shown), thereby suggesting that part of the $\mathrm{Zn}$ might be effectively retained by the column. As a consequence, the increase of the $\mathrm{Zn}$ baseline might be attributed to the gradual release of this element from the column with increasing acetate concentration. Although positively charged ions (e.g., $\mathrm{Zn}^{2+}$ ) should not be retained by the column, the presence of different counter ions (e.g., acetate, chloride) might be involved in this unexpected adsorption phenomenon. Considering that reproducible and accurate speciation of $\mathrm{Zn}$ with anion exchange chromatography coupled with ICP-MS detection is a common problem [12], further research will be needed to improve the analysis of $\mathrm{Zn}$ species with this technique.

In the current work, we also showed that large differences within some species ( $\mathrm{Fe} 1, \mathrm{Cu} 2$, and $\mathrm{Se} 1)$ are responsible for the differences in the total amount of $\mathrm{Fe}, \mathrm{Cu}$, and Se between Seronorm L1 (lot 0608414) and Seronorm L2 (lot NO0371z) reference material. It has been reported that Seronorm L2 material could be obtained by spiking a regular serum sample with inorganic elements (e.g., Se) to obtain a high level of certain elements [20]. Therefore, a contribution to $\mathrm{Fe} 1, \mathrm{Cu} 2$, and $\mathrm{Se} 1$ could derive from inorganic $\mathrm{Fe}, \mathrm{Cu}$, and Se. Anyway, the results provided here for $\mathrm{Fe}, \mathrm{Cu}$, and $\mathrm{Se}$ in these materials can be used for reference purposes in future validation of speciation methods and/or for interlaboratory comparisons.

The current method allows working in a very limited amount of biological sample; thus, it may be properly used in multicenter projects where biological material needs to be shared among many 

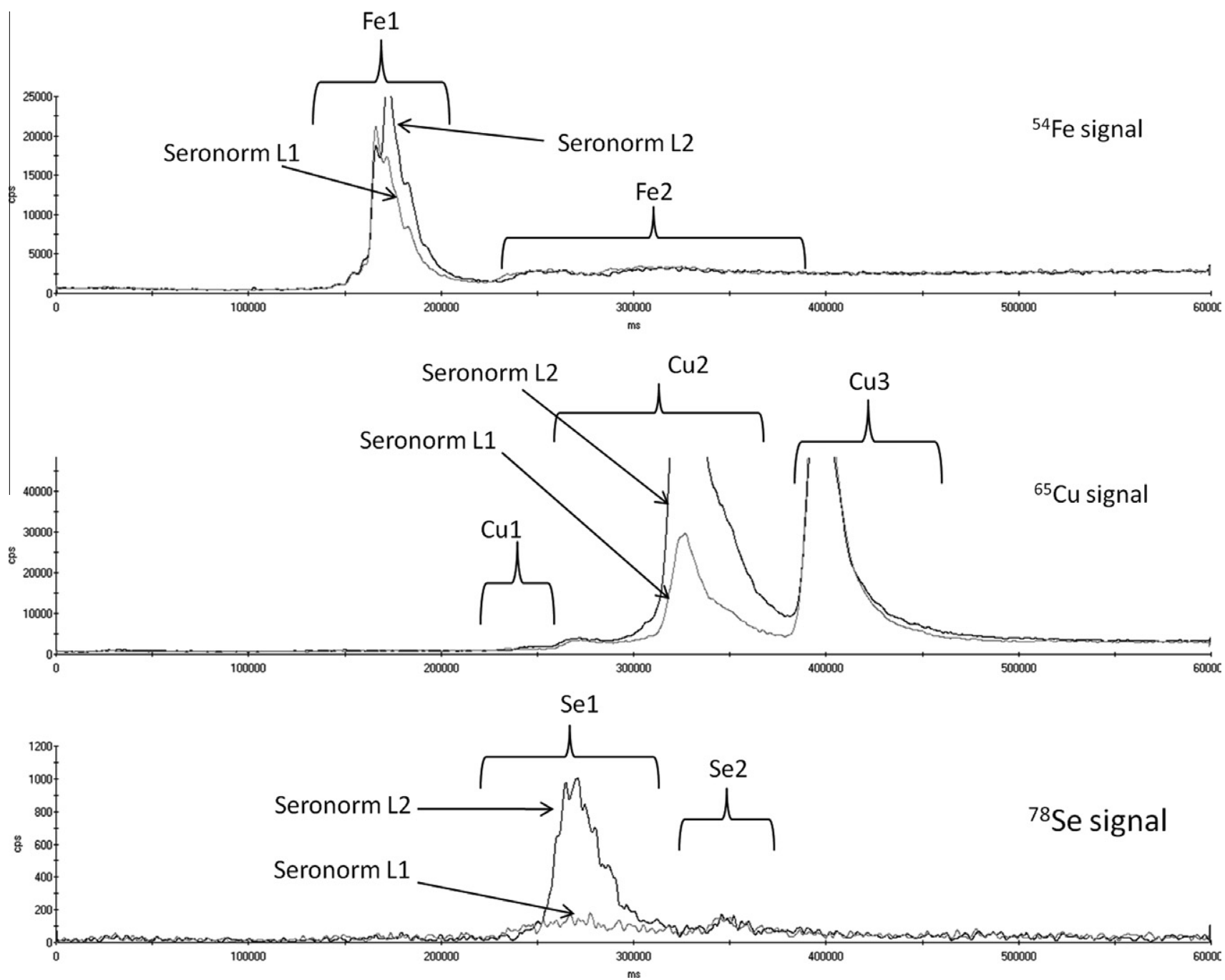

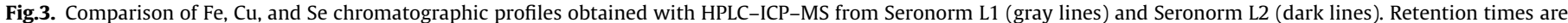
reported in milliseconds (ms) as originally displayed.

Table 5

Comparison of element species obtained from human serum, EDTA plasma, and Li-He plasma obtained from healthy donors.

\begin{tabular}{|c|c|c|c|c|c|c|c|c|c|}
\hline & $\begin{array}{l}\text { Fe1 } \\
\text { Mean } \\
\text { ppb } \\
(\mathrm{SD})\end{array}$ & $\begin{array}{l}\text { Fe2 } \\
\text { Mean } \\
\text { ppb } \\
\text { (SD) }\end{array}$ & $\begin{array}{l}\text { Cu1 } \\
\text { Mean } \\
\text { ppb } \\
\text { (SD) }\end{array}$ & $\begin{array}{l}\text { Cu2 } \\
\text { Mean } \\
\text { ppb } \\
\text { (SD) }\end{array}$ & $\begin{array}{l}\text { Cu3 } \\
\text { Mean } \\
\text { ppb } \\
\text { (SD) }\end{array}$ & $\begin{array}{l}\text { Zn1 } \\
\text { Mean } \\
\text { ppb } \\
\text { (SD) }\end{array}$ & $\begin{array}{l}\text { Zn2 } \\
\text { Mean } \\
\text { ppb } \\
\text { (SD) }\end{array}$ & $\begin{array}{l}\text { Se1 } \\
\text { Mean } \\
\text { ppb } \\
\text { (SD) }\end{array}$ & $\begin{array}{l}\text { Se2 } \\
\text { Mean } \\
\text { ppb } \\
\text { (SD) }\end{array}$ \\
\hline Serum $(n=12)$ & $1351(202)$ & $974(497)$ & $105(32)$ & $337(55)$ & $1634(251)$ & 930 (219) & $28(9)$ & $66(10)$ & $38(6)$ \\
\hline Li-He plasma $(n=12)$ & $1288(141)$ & $787(320)$ & $83(13)$ & $330(77)$ & $1602(182)$ & $848(153)$ & $30(11)$ & $60(9)$ & $34(6)$ \\
\hline EDTA plasma $(n=12)$ & $777^{* *}(63)$ & $3874^{* * *}(1619)$ & $829^{* *}(439)$ & $873^{* *}(267)$ & $1631(260)$ & $2754^{* *}(342)$ & $57^{*}(26)$ & $62(8)$ & $37(6)$ \\
\hline
\end{tabular}

Note. Comparison among serum, EDTA plasma, and Li-He plasma was performed by repeated-measures ANOVA followed by Bonferroni post hoc test.

${ }^{*} P<0.01$ compared with serum or Li-He plasma.

** $P<0.001$ compared with serum or Li-He plasma.

partners or for retrospective studies using material stored in biological banks. Several biobanks have stored serum or plasma samples collected with different anticoagulants (usually EDTA or $\mathrm{Li}-\mathrm{He}$ ). Because these anticoagulants can affect speciation of trace elements in human plasma, we compared speciation of $\mathrm{Fe}, \mathrm{Cu}, \mathrm{Zn}$, and Se among Li-He plasma, EDTA plasma, and serum obtained from healthy young volunteers.

We did not observe significant differences in the distribution of $\mathrm{Zn}, \mathrm{Cu}, \mathrm{Fe}$, and Se between human heparinized plasma and serum, thereby suggesting that heparin plasma could be a useful alternative to serum when performing speciation analysis with this method. A trend versus higher levels of Fe 2 was observed in serum. This difference, although not significant, might deserve particular attention because it could arise from the presence of trace contaminations of Fe bound to residual hemoglobin in hemolytic serum samples. Indeed, abnormally increased Fe2 peaks were found in completely hemolytic samples (data not shown).

In contrast to heparin plasma, samples collected using EDTA strongly affect speciation analysis. However, these samples might also be considered for particular analysis taking into account that 

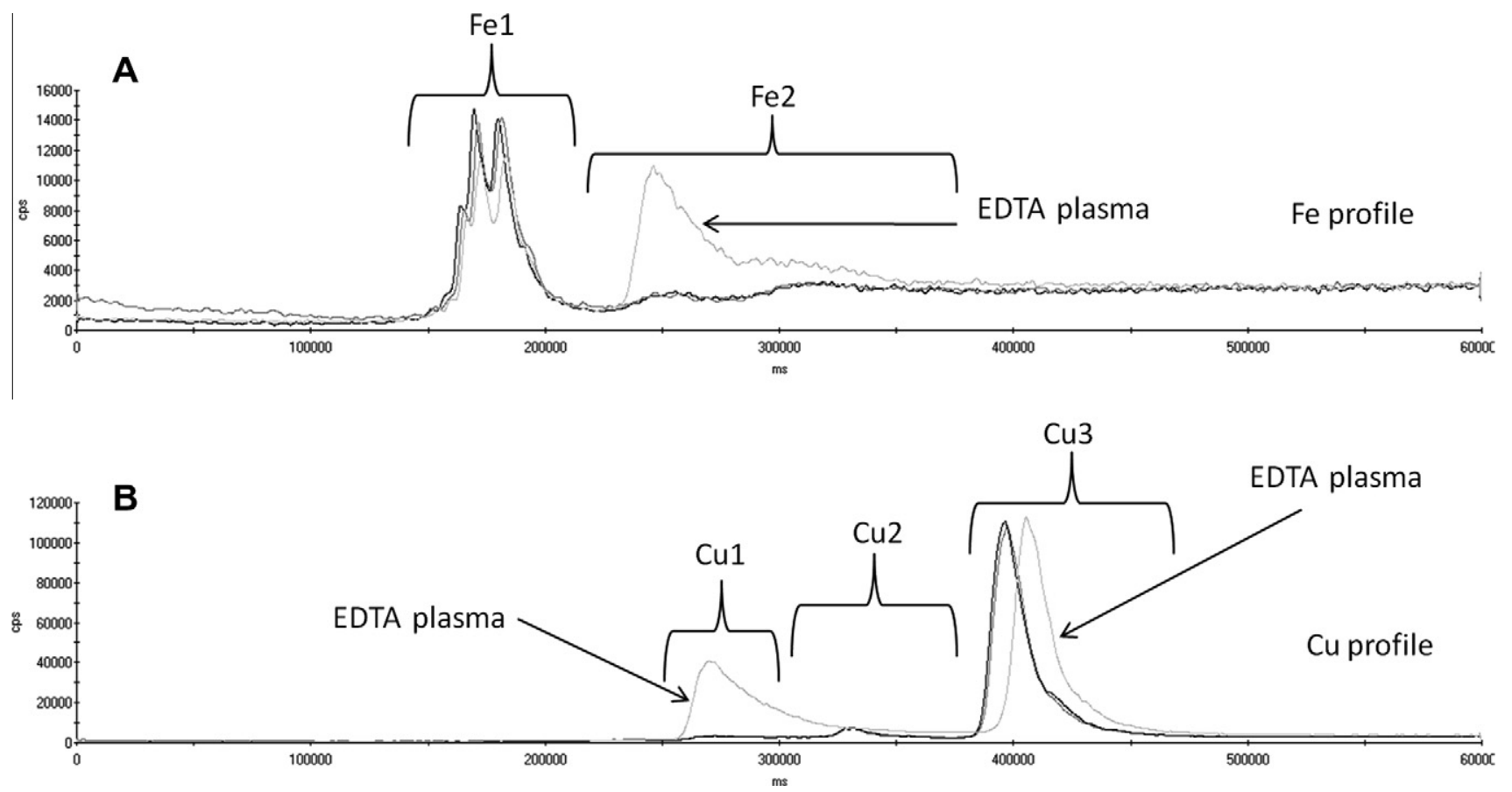

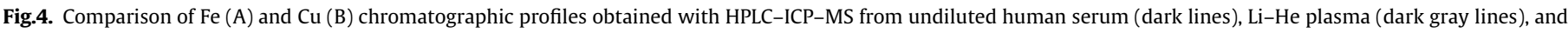
EDTA plasma (gray lines) obtained from healthy adult donors. Retention times are reported in milliseconds (ms) as originally displayed.

data for $\mathrm{Cu} 3$ and Se species remain similar to those obtained from serum or heparin plasma (Fig. 4 and Table 5). The reason why EDTA changes the profile of $\mathrm{Cu}, \mathrm{Zn}$, and Fe while preserving the Se profile could be found in the chemistry of biological Se species. In the living body (in contrast to metal-protein complexes that can be altered by EDTA), Se is not bound by coordination but forms covalent carbon-selenium bonds. As a consequence, the Se profile might not be affected by EDTA because it is rather unlikely that this chelator could be able to break the carbon-selenium bond.

Other nonprotein selenium species that can be found in biological fluids include inorganic selenium such as selenite $\left(\mathrm{SeO}_{3}^{2-}\right)$ and selenate $\left(\mathrm{SeO}_{4}^{2-}\right)$, which are negatively charged ions without affinity for EDTA.

Regarding the nature of the proteins that bind to the elements reported in the chromatographic peaks, we noted that our method offers a separation quite identical to that in a previous study that attempted to assign these peaks [10]. In agreement with the previous study, the injection of purified ceruloplasmin (data not shown) suggested that the largest peak in the $\mathrm{Cu}$ chromatogram ( $\mathrm{Cu} 3$ in our chromatograms) might be assigned to ceruloplasmin. Indeed, most $\mathrm{Cu}$ is bound to ceruloplasmin in human serum, with the rest being bound to albumin and approximately $1 \%$ being ionic or bound to low-molecular-weight fractions [10]. Therefore, Cu3 can be assigned to ceruloplasmin or, at least, to an isoform of this protein. Because high ceruloplasmin concentrations in serum are significantly associated with risk of heart failure and cardiovascular disease [21,22], the current method might be useful in research for the identification of risk factors for cardiovascular diseases when also taking into account the improved throughput and reduced costs of this approach compared with other speciation methods $[10,12]$.

Fe species eluted in two main fractions, as reported by others [10]; the first fraction ( $\mathrm{Fe} 1$ ) was assigned to Fe bound to transferrin, and the second one (Fe2) was assigned to Fe bound to albumin. The assignment of $\mathrm{Fe} 1$ to transferrin was confirmed in this work by the retention time of purified transferrin (data not shown). However, the various subpeaks identified within $\mathrm{Fe} 2$ and its relative amounts suggest that this peak (Fe2) could be formed from different species that currently cannot be assigned. Zn eluted in a "big fraction" composed of several peaks and a separate small peak eluting together with Cu3 (Fig. 2). As observed previously, the type of separation selected (SAX) might alter the eventual speciation of $\mathrm{Zn}$ in serum. $\mathrm{Zn}$ is known to be bound to albumin (60-70\%), $\alpha_{2}$-macroglobulin (30-40\%), and transferrin (1-2\%) [10]. Therefore, it remains difficult to assign the species observed when also taking into account that distribution of $Z n$ within peaks of the big fraction was not reproducible. Finally, Se is known to be bound to plasma glutathione peroxidase (15-25\%), selenoprotein P (50-60\%), and albumin (10-20\%) [10]. The first peak of Se coelutes with the big fraction of zinc, thereby suggesting that Se1 might include Se bound to albumin. However, further investigations combining this separation with "time-of-flight" or other detection systems [20] will be required to definitively assign all of the species of the trace elements studied here.

\section{Conclusions}

Speciation analysis is an important discipline that allows one to study and better understand the pathway of elements in the human body. The proposed method involving tandem SAX chromatography separation might find future application for a very fast screening of changes of trace elements distribution in serum among individuals caused by various diseases or treatment or physiological changes (i.e., age-related changes). The procedure could also be applied for comparative studies of different element species using Li-He plasma as well as to study Se species and ceruloplasmin ( $\mathrm{Cu} 3$ peak) in EDTA plasma samples given that the amount of these species was not dramatically affected by the anticoagulant.

\section{Acknowledgment}

This work was supported by a grant from the European Union within the FP7 Framework: Project MARK-AGE (HEALTH-F42008-200880). 


\section{References}

[1] R. Cornelis, F. Borguet, J. De Kimpe, Trace elements in medicine: speciationThe new frontier, Anal. Chim. Acta 283 (1993) 183-189.

[2] P. Bratter, A. Raab, A.N. Richarz, in: A.M. Roussel, R.A. Anderson, A.E. Favrier (Eds.), Trace Elements in Man and Animals 10, Springer, New York, 2000, pp. 145-152.

[3] B. Michalke, The coupling of LC to ICP-MS in element speciation: I. General aspects, Trends Anal. Chem. 21 (2002) 142-153.

[4] A. Sanz-Medel, M. Montes-Bayón, M. Luisa Fernández Sánchez, Trace element speciation by ICP-MS in large biomolecules and its potential for proteomics, Anal. Bioanal. Chem. 377 (2003) 236-247.

[5] A. Raab, P. Brätter, Separation of metalloprotein complexes in serum by sizeexclusion chromatography: optimisation of the separation parameters retention behaviour and recovery employing radiotracers, J. Chromatogr. B 707 (1998) 17-24

[6] J. Wang, R.S. Houk, D. Dreessen, D.R. Wiederin, Speciation of trace elements in proteins in human and bovine serum by size exclusion chromatography and inductively coupled plasma-mass spectrometry with a magnetic sector mass spectrometer, J. Biol. Inorg. Chem. 4 (1999) 546-553.

[7] V. Nischwitz, A. Berthele, B. Michalke, Speciation analysis of selected metals and determination of their total contents in paired serum and cerebrospinal fluid samples: an approach to investigate the permeability of the human blood-cerebrospinal fluid barrier, Anal. Chim. Acta 627 (2008) 258-269.

[8] M. Malavolta, F. Piacenza, L. Costarelli, R. Giacconi, E. Muti, C. Cipriano, S. Tesei S. Spezia, E. Mocchegiani, Combining UHR-SEC-HPLC-ICP-MS with flow cytometry to quantify metallothioneins and to study zinc homeostasis in human PBMC, J. Anal. At. Spectrom. 22 (2007) 1193-1198.

[9] T. Tomono, H. Ikeda, E. Tokunaga, High-performance ion-exchange chromatography of plasma proteins, J. Chromatogr. 266 (1983) 39-47.

[10] C.S. Muñiz, J.M. Marchante-Gayón, J. García Alonso, A. Sanz-Medel, Speciation of essential elements in human serum using anion exchange chromatography coupled to post-column isotope dilution analysis with double focusing ICPMS, J. Anal. At. Spectrom. 16 (2001) 587-592.

[11] S. Arizaga Rodríguez, E. Blanco González, G. Alvarez Llamas, M. Montes-Bayón, A. Sanz-Medel, Detection of transferrin isoforms in human serum: comparison of UV and ICP-MS detection after CZE and HPLC separations, Anal. Bioanal. Chem. 383 (2005) 390-397.

[12] O. Mestek, J. Kominkova, R. Koplik, M. Kodicek, T. Zima, Quantification of trace elements in human serum fractions by liquid chromatography and inductively coupled plasma mass spectrometry, Appl. Organomet. Chem. 21 (2007) 5-14.

[13] T. Hasegawa, Y. Wakita, Y. Zhu, H. Matsuura, H. Haraguchi, T. Umemura, Speciation of human serum proteins based on trace metal mapping analysis by CIM monolithic disk column HPLC/ICP-MS in complement with off-line MALDI-TOF-MS analysis, Bull. Chem. Soc. Jpn. 80 (2007) 503-550.

[14] P.J. Parsons, in: R.A. Myers (Ed.), Encyclopedia of Analytical Chemistry, John Wiley, Chichester, UK, 2000, pp. 1091-1123.

[15] R. Forrer, K. Gautschi, H. Lutz, Simultaneous measurement of the trace elements $\mathrm{Al}, \mathrm{As}, \mathrm{B}, \mathrm{Be}, \mathrm{Cd}, \mathrm{Co}, \mathrm{Cu}, \mathrm{Fe}, \mathrm{Li}, \mathrm{Mn}, \mathrm{Mo}, \mathrm{Ni}, \mathrm{Rb}, \mathrm{Se}, \mathrm{Sr}$, and $\mathrm{Zn}$ in human serum and their reference ranges by ICP-MS, Biol. Trace Elem. Res. 80 (2001) 77-93.

[16] I. De Blas Bravo, R. Sanz Castro, N. López Riquelme, C. Tormo Díaz, D. Apraiz Goyenaga, Optimization of the trace element determination by ICP-MS in human blood serum, J. Trace Elem. Med. Biol. 21 (Suppl. 1) (2007) 14-17.

[17] M. Malavolta, R. Giacconi, F. Piacenza, L. Santarelli, C. Cipriano, L. Costarelli, S. Tesei, S. Pierpaoli, A. Basso, R. Galeazzi, F. Lattanzio, E. Mocchegiani, Plasma copper/zinc ratio: an inflammatory/nutritional biomarker as predictor of allcause mortality in elderly population, Biogerontology 11 (2010) 309-319.

[18] D.B. Milne, in: C.A. Burtis, E.R. Ashwood (Eds.), Tietz Textbook of Clinical Chemistry, W. B. Saunders, Philadelphia, 1994, pp. 1315-1353.

[19] A. Townsend, A. Featherstone, C.C. Chéry, F. Vanhaecke, J. Kirby, F. Krikowa, B. Maher, G. Jacobson, G. Peterson, Increased selenium concentrations in Seronorm trace elements serum (level 2), Clin. Chem. 50 (2004) 1481-1482.

[20] P. Jitaru, H. Goenaga-Infante, S. Vaslin-Reimann, P. Fisicaro, A systematic approach to the accurate quantification of selenium in serum selenoalbumin by HPLC-ICP-MS, Anal. Chim. Acta 657 (2010) 100-107.

[21] G. Engström, B. Hedblad, P. Tydén, F. Lindgärde, Inflammation-sensitive plasma proteins are associated with increased incidence of heart failure: a population-based cohort study, Atherosclerosis 202 (2009) 617-622.

[22] N.D. Brunetti, P.L. Pellegrino, M. Correale, L. De Gennaro, A. Cuculo, M. Di Biase, Acute phase proteins and systolic dysfunction in subjects with acute myocardial infarction, J. Thromb. Thrombolysis 26 (2008) 196-202. 